\title{
Constructing and reviewing dioramas : Supporting beginning teachers to think about their use to help children understand the work of natural history scientists
}

\author{
McGregor, Deb and Gadd, Jennifer \\ Submitted for : \\ Scheersoi, A. \& Tunniclffe, S.D.: Natural history dioramas - Traditional \\ Exhibits
}

\section{Synopsis}

This chapter will explore beginning teachers' views of the use of dioramas to teach young children about scientists who have contributed to our understandings about Natural History.

Recent changes to the English National Curriculum have resulted in re-focusing learners to consider not only what do we know about an area of science today, but also, how did we come to know (and whom was responsible) for discovering theories we learn about in school. Hypotheses (and evidence) that enabled scientists to recognise the process of survival of the fittest; the ways that fossils are representative of different geological eras have helped us consider (and understand) why the form and function of plants and animals has changed over time and how pollutants, too, have caused changes in survival rates of particular animals are all contributory to appreciating Natural History. The scientific work of that people, such as David Attenborough, Charles Darwin, Mary Anning, Rachel Carson and Jane Goodall have carried out will be considered through the ways that learners could use dioramas to convey aspects of their 'stories'.

Constructing dioramas can help beginning teachers appreciate how a more concrete, direct, 'hands-on' approach using everyday materials, can offer affordance to make complex ideas easier for younger children to understand. This chapter also describes, what they, as beginning teachers, reflected on through making a series of dioramas to depict the ways that the different scientists have contributed to our understanding of Natural History in some way. They also considered how it was a useful approach for young children, not only to make the dioramas, but also review each others and create a class collection of 'models' to help understand what we know (and how) about Natural History.

This chapter, therefore, is written about a piece of evaluative action research undertaken to explore what beginning teachers learn (and think) about the use of dioramas to help children understand natural history. 


\section{Introduction}

Dioramas have traditionally been used to present realistic glass-cased representations of a range of habitats and the flora and fauna that naturalistically coexist there (Tunniciffe and Scheersoi 2015). These kinds of three-dimensional models have provided static exhibits typically found in museums aiming to showcase for visitors illustrations of the specimens that normally inhabit particular ecological contexts. These reconstructed environments can provide miniature (or even life-sized) representations of typical landscapes and their natural inhabitants. Classically these dioramas have included a background painted to provide perspective and a context as well as preserved animal and plant specimens (Reiss and Tunnicliffe 2011). Reiss and Tunnicliffe (ibid) discuss how varied the scenes can be (from an Angolan savannah with impala and wildebeest in it, to wild Alaskan landscapes containing mythical creatures such as Valhalla and even a Kenyan watering hole with grazing giraffes) to illustrate for visitors narratives or stories about wildlife, with a view to offering opportunities for learning through interpretation by viewers. Piqueras et al (2012) discuss further how dioramas have also been constructed to purposely present intrigue for viewers within a display. They describe a diorama with a female white-tailed eagle eating the remains of a roe deer in a snowy landscape. In the distance there are a pair of hooded crows (ibid $2012: 81$ ) watching and waiting, perhaps considering ways to steal food from the eagle! There are also fox footprints in the artificial snow and the deer's head is missing (apparently is it common place for foxes to take away the heads of the animals they have hunted). The aim of this 'scene' is to promote visitors' curiosity about the relationships between the animals in the snowy setting and to wonder about what has happened and what might unfold next. The aim of the diorama displays with beginning teachers, in the study reported here, was to raise their awareness and appreciation of the potential use of dioramas to teach about natural history. It was hoped that the students would engage in reflecting about how constructing and reviewing dioramas developed understanding about natural history. Some of the dioramas the students produced, did indeed offer opportunities to wonder about (and deliberate over) the story being told through the displays. It was assumed that through working with others, in a socially constructivist manner, toward the common purpose of generating a series of home-made dioramas presented in a museum-like display, would provide a mutually useful interactive learning experience for everyone (Falk and Dierking 2000; Falk et al 2004). The objective was to invite each other to view their home-made dioramas to cogitate on whose natural history work might be portrayed in each shoe-box model. The intent was also to engage the beginning teachers in reflecting on their experience of constructing and inspecting dioramas to consider how they might be useful in future for (their own) teaching. There was also an attempt to explore whether the processes of making and reviewing could extend Tunnicliffe and Scheersoi's (2010) four-stage response, cited in Rennie 2014 (p.125), of "identify - interest - interpret - investigate" to dioramas. The evaluative approach of the workshop-like session explored, as Jakobsson and Davidsson (2012) suggest how the production of artefacts (the student-constructed dioramas) contributed to, and mediated learning.

\section{The approach}

The project reported on is a piece of evaluative action-research carried out by two tutors at Oxford Brookes University. It was undertaken to explore what (and how) beginning teachers could learn about natural history through making dioramas. The interventional experience, described in more detail later was designed as an active collaborative workshop session whereby the students co-constructed home-made dioramas in triads. On-going conversations, reflective discussion (and responses to an evaluative questionnaire at the end of the session) suggested how dioramas were 
helpful in learning about natural history and how they might be more effectively utilised to support learning in future.

\section{Focusing the diorama-making on content required by English schools}

Trainee primary school teachers in England learn to teach 5-11 year old children. Whilst training they need to develop a range of pedagogical skills to deliver a high quality education whilst also demonstrating the subject knowledge required to teach 11 different subjects in the Department for Education's Primary National Curriculum (2013). Of these 11 subjects, three are considered 'core' subjects; mathematics, literacy and science.

The science curriculum is intended to allow children to 'develop a sense of excitement and curiosity about natural phenomena' (2013: 144). It is divided up into years groups and then into different biology, chemistry and physics topics. Each year group has at least one topic related to natural history; either plant biology, human biology or animal biology.

The national curriculum has 'statutory requirements' which must be taught, but also a 'notes' section with a suggestion for lesson ideas and objectives. For each topic a famous scientist is recommended as one to study. For the natural history topics, these could include David Attenborough, Jane Goodall, Mary Anning, Rachel Carson and Charles Darwin. In addition, an objective for pupils in year six (aged 11 and 12 years old) is to be able to 'talk about how scientific ideas have developed over time' (2013: 166). These beginning teachers therefore needed to be familiar with each of these scientists and their work in order to teach children about them effectively. This workshop was thus devised to explore how classroom dioramas support and mediate teaching this aspect of the curriculum.

\section{The students involved in the project}

Oxford Brookes University trains approximately 600 students a year to become primary school teachers teaching 5-11 year old children. There are many different training routes including a one year long course for post-graduates, and a three year long course for undergraduates. Regardless of the route taken into teaching, these 'beginning teachers' are given workshops, seminars and lectures in all aspects of the national curriculum by subject experts in order to ensure that they have both the pedagogical skills and subject knowledge required to teach.

For the purposes of this action research project the second year cohort of beginning teachers were invited to be involved. The cohort consisted of 71 students aged between 19 and 35 years old. All of the beginning teachers had experienced at least 12 weeks of working in a primary school and were in the process of preparing for a further 8 week long placement. As a result they had some experience in working with young children and were developing their pedagogic expertise and subject knowledge. On their placements, the majority of students had taught one science lesson each on any topic. Their reflective comments, therefore, are based on a brief, initial experience as a beginning teacher in school.

\section{The diorama workshop session}

In the second year of the Batchelor of Arts (Educational Studies) degree course, the beginning teachers are engaged in eighteen workshops or seminars lasting one and a half hours per week. Each of these seminars focuses on a different aspect of subject knowledge. For the purposes of this evaluative project, a new seminar was designed. The intention of this seminar was two-fold. Firstly, the main intention of the seminar was to introduce the beginning teachers to the scientific contributions and personal stories of the natural history scientists named in the 'notes' section of the national curriculum; David Attenborough, Jane Goodall, Mary Anning, Rachel Carson and Charles Darwin. Secondly, the seminar aimed to allow beginning teachers to experience, in role as primary aged children, the process of constructing (and 
examining) a diorama and to consider the benefits of conducting a similar activity, through creating a museum-like display in a classroom in school.

To assess the student's familiarity with dioramas they were asked about their views and previous experience of them. The 71 beginning teachers were split into 3 (successive) teaching groups organised to work in (mostly) triads to work on their diorama projects together. Each trio was allocated a card with the name of a scientist written on. These were distributed at random. The students were requested not to divulge which scientist they had been allocated, they were invited to 'reveal' their scientist through their displays. Each group of three were given a shoe box within which to create a diorama, and a range of everyday modelling materials such as paper, card, tissue, coloured sellophane, paints, hot glue guns and cutting knives. Before beginning to make the dioramas, the beginning teachers were invited to create their own success criteria for their displays. They were asked to consider what they might expect a primary school child to achieve during the activity. It was determined that, in order to be successful, the following would need to be achieved during the activity:

- The diorama should depict the scientist and their contribution to the field of natural history including what they looked like and what they achieved.

- Other students should be able to work-out which scientist was depicted by looking at the diorama.

- The diorama should be accompanied by a 'fact sheet' of key ideas about the scientist's life and work (a cultural convention noted by Achiam et al (2014 : 4) to relate to a real museum exhibit).

- The students should work collaboratively in their group, taking turns and negotiating when making decisions about what or how to make something.

- The diorama needed to be fully complete within an hour of creation time.

During the creation of the dioramas the beginning teachers were provided with a tablet computer connected to the internet in order to research their scientist fully. They were encouraged to find out as much as they could about the scientist's personal life and their contribution to the field of natural history. The tutors moved from group to group collecting field notes and photographs (see Figures $1-5$ ) to document the artefact-construction-process. Once the building-dioramas phase was complete the beginning teachers then took time to visit the other dioramas as if at a local museum reviewing the display boxes. Each group jointly construed their explanatory narratives about which Natural History scientist was portrayed and then verified their predictions through uncovering and reading the accompanying fact sheet. Utilising the success criteria they also considered how well each diorama achieved the display aims. Photographs of some of the finished artefacts were taken (see Figures $5 a-5 d$ ).

Finally, the students were invited to complete a short questionnaire. They were asked to consider how they would describe a diorama; what they thought they learned through making a diorama; what they thought they learned through reviewing others' dioramas; which areas of science lent themselves to-be-learnt-about through making-your-own-diorama; what they thought children might benefit from through dioramas and whether there were particular stages in learning where they were most helpful. The students were also asked about their understanding of the focus of the dioramas, the natural history scientists.

\section{Findings}

Views of dioramas before being introduced to them 
Prior to the diorama session, there were quite a variety of views about the possible nature of dioramas, and $24 \%$, nearly a quarter of the students had not heard of them, reflecting Tunnicliffe and Scheersoi's (2015) view that these kinds of museum exhibits are little used and appreciated for their potential contribution to science education. Most of the students (who had heard of dioramas) considered them to be some kind of 'mini-stage' or 'miniature scene' illustrating a particular landscape or vista of some kind. Few specifically mentioned 'habitats'.

\section{Post session views of the nature of a diorama}

After the experience of making their own and reviewing others' unique constructions, the majority of the students defined dioramas as 3D models of something offering a visual representation of a person, event, moment-in-time or a scene of some kind. During the session re-cycled shoe boxes (see Figures 1 to 5 ) were used to create the in-expensive dioramas. So although the students did not engage in constructing dioramas that were traditionally assembled in open or sealed transparent glass cases they certainly recognised how the opportunity to craft a mini-scene portrayal of the story about a natural history scientist's work, provided a creative and enjoyable learning experience. They also recognised how a form of reality was depicted within them and even though the home-made (and not constructed to-scale) dioramas could provide an effective display to aid viewers memorable understanding of something. They recognised that it was possible to fashion dioramas to convey a range of aspects related to natural history including habitats, animals, plants, seasons, life cycles and even evolution.

\section{Students' views of their learning from engaging in making the dioramas?}

Learning about dioramas through collaboratively constructing them

When reporting on collaboratively constructing the dioramas, the students indicated it was fun and suggested the 3D displays were surprisingly easy to make! They also thought it was an effective and useful way to learn and generally a successful and engaging experience. In the process of making the kinds of skills that they suggested were required included using colour (see Figure 1) to convey a context, such as the woodland (see Figure 3), sky (Figure 2), beach, under-the-sea (see Figures 5b,d) or jungle (see Figure $5 \mathrm{c}$ ). Creating a 3D space or sufficient area to be able to generate depth (through layers) in the dioramas meant that some triads chose to utilise the boxes in different ways. One group generated much more depth of field by adopting the lid as part of the base, another group wanted to present their 'scene' as a plan view rather than from a side elevation (Figures 5a, b, c, d). Another group literally created a 'window' to peer into a moment-in-time of the life of a scientist.

Learning about natural history scientists, their life and work

$79 \%$ of the students recognised, that through the preparatory processes required to build the shoe-box diorama artefact, they encountered and made sense of significantly more information about the scientists than they had previously been aware of. In their joint endeavours to design and plan the construction of the dioramas most of the students indicated they learned much more about the lives and work of Darwin, Attenborough, Goodall, Anning and Carson.

Working together collaboratively, to make a display, more than just 'arrests attention' (Reiss and Tunnicliffe $2011: 447$ ) of learners, it can offer direct affordance by engaging them in transformative thinking about the object of focus for would-beviewers. As Rounds (2004) indicates selecting a particular element or aspect (in this study of scientists' lives) to pique curiosity can draw attention of visitors to an exhibit. The to-and-fro discussion, between learners, deliberating over how they will 
construct a particular depiction (with a variety of everyday materials) promotes consideration of the narrative they want to communicate about the key work of the scientist. Co-constructing with others, a jointly agreed design of aspects of reality from the scientist's work can involve in-depth reflection of ways to represent some kind of phenomena related to natural history.

Some students noted that making the shoe-box dioramas was time consuming. This could be due to the challenge to decide how to depict concepts in an accurate and precise manner within a tight time frame. As Cole (1996) suggests, artefacts, such as the shoe-box dioramas are created and developed during the interactions between the collaborating individuals. The dialectic exchanges involving the to-and-fro considerations regarding the 'make-do' materials rather than the taxidermists real preserved specimens (Tunnicliffe and Reiss 2011) that would be more readily available for museums to create their collections.

\section{Learning through constructing a diorama}

The specific learning processes that the students indicated they felt they engaged in, included researching information (related to Figure 4); transforming or re-presenting key information; modelling in miniature or at least somewhat in proportion so the representations can be accurately interpreted. Prioritising what should be the focus of the Darwin (see Figure 5a), Attenborough, Goodall (see Figure 5c), Anning (see Figure 5b) or Carson (see Figure 5d) dioramas promotes criticality reviewing extensive information to select salient facts to include in a display. To synthesize, collate and simply summarise to represent observing primates (Goodall) or the process of evolution (Darwin) or recognising the causal relationship of the slow deterioration of something in the environment as a consequence of an accruing pollutants over time (Carson), for example, are challenging concepts to convey. Examples of the ways in which narratives about the scientists and their work were understood through the participatory process of making a diorama include one student, for example, developing his appreciation of Darwin from "He discovered a lot of things" to knowing that he was born in Shrewsbury, and he travelled to the Galapagos Islands, where he carried out much of his work and developed his theory of evolution. Another student before the activity indicated he knew Darwin was "British", but after the diorama session he knew more specifically that this scientist developed the theory of evolution through his work on finches on the Galapagos Islands. Other additional information students garnered included details about Darwin's publications and the specificity of his work that evidenced natural selection through looking at finches beaks and the ways they were adapted to collect berries, eat prickly cacti or insects, for example. The final dioramas produced (see Figure $5 a, b, c, d)$ illustrate how the groups focused on differing aspects of the Natural History scientists work to illustrate. Figure 5a, for example, highlights how Darwin's Origin of Species included a description of the evolution of man from primates; another diorama highlighted more specifically work, symbolised with an enlarged magnifying lens, carried out on beaks of finches in the Galapagos Islands and a third one clearly recognised the variation in the general morphology of the finches. Each of these three different examples of home-made shoe-box dioramas provided clear indications of the ways that similar information is 'storied' quite differently by the students. This illustrates how Vygotsky's (1978) argument that thoughts are created and conveyed through using cultural tools (such as everyday materials in this case). The reified artefacts (the dioramas) that emerged varied because they were produced through the dialectical relationships involving the minds and socio-historical experiences informing the contributions from the students. The variation of interpretations can enrich the reflective discussion and subsequently what is understood about Darwin's natural history work. The students indicated they learned more about David Attenborough and his work too through constructing the dioramas. 
Many students recognised prior to making dioramas that he was a presenter of natural history on television and that he made documentaries about animals, but until they engaged in researching his work they did not realise the geographical and biological extent of his natural history knowledge and expertise. The dioramas that depicted his life and work illustrated different contexts (watering hole, jungle and polar regions respectively) and facets of his work (openly observing, hiding unseen and requiring binoculars to view animals in situ in their habitat, quotations about 'penguins as the warriors of the polar regions'). It seemed that creating dioramas, in this way, offered the beginning teachers (as learners) the space and opportunity to generate interpretative narratives (Achiam et al 2014).

The students knew very little about Jane Goodall prior to the diorama session (in fact only 9 students were familiar with her name), but by the time the session had finished many had developed understanding about her work, as a primatologist, from just concerning gorillas, to recognising how and when she studied a wide range of apes (including chimpanzees, gorillas and monkeys) in Tanzania. Three dioramas depicted her work in contrasting ways. The first provided a window into the habitat within which she studied chimpanzees symbolised by the brown monkey type shapes with oversized bananas!; the second included a representation of a jungle-like habitat with a group of gorrillas in a natural setting, where there was a hut-like building from where Goodall might have lived and observed the animals; the final diorama appeared to represent Goodall as an expert on gorrillas explaining their behaviour. The dioramas of Mary Anning included illustrating her at the beach with her pet dog where there were shells (depicting fossils); the second one provided additional portrayals of an ichthyosaur and an indication of its location in a coastal cliff; the third one just focussed on the sea, beach and cliff-side habitats. Students indicated a fivefold increase in their understanding of her somewhat scavenging life-style on the Lyme Regis coastline through using these scenic displays.

The final scientist considered in the diorama activity was Rachel Carson. None of the students had heard of her prior to the diorama activity. The shoe-box display of Carson's work emphasized the under-the-sea habitat she was concerned about, the creatures that inhabit it and the trash that pollutes it. From knowing nothing about this scientist the students came to realise she possessed keen observational skills informing her hypothesis about the causal relationship between pollution and the detriment of organism's reproductive capacity.

\section{Learning about the Natural History scientists}

Students reporting what they learned about the various scientists through engaging in constructing their group displays and viewing others' dioramas are shown in Table 1. Interestingly, they indicated that there was much more impact when they were considering (making and reviewing representations of) people they knew little about or had not encountered before (eg: Goodall, Anning and Carson). It appeared that using the diorama activity to develop understanding and familiarity with the work of Darwin and Attenborough, scientists they already knew something about, did not promote quite so much impact on learning about their lives and natural history work.

\begin{tabular}{|c|c|c|}
\hline & $\begin{array}{c}\text { Comments prior to the } \\
\text { activity }\end{array}$ & $\begin{array}{c}\text { Comments after } \\
\text { diorama construction } \\
\text { and review }\end{array}$ \\
\hline Darwin & 91 & 79 \\
\hline Attenborough & 82 & 89 \\
\hline Goodall & 9 & 52 \\
\hline Anning & 7 & 38 \\
\hline Carson & 0 & 15 \\
\hline
\end{tabular}


Table 1 : Beginning teachers' views of perceived affordance of making and reviewing co-constructed dioramas.

Although Reiss and Tunnicliffe (2011) emphasize how exhibits are used to relay particular stories in museums, having (teachers and) children create their own dioramas offers learners more affordance in a variety of ways. Arguably, challenging the students to create and construct their own dioramas, offered them a 'real' and 'material' design affordance (Norman 1999) that was physical, in the sense that they handled the resources that they used to communicate something with. Because there will inevitably be a difference in the way that the same display purposely designed to portray the work of Jane Goodall (Figure 5c), for example, will be interpreted differently by viewers. Those looking at the same diorama may assign quite different meanings to the presence of the construct that could be a house, hut or hide in the shoe-box. It is anticipating the variation of interpretations that generate different stories (perhaps Jane lived there permanently or used it occasionally during observational episodes as a hide when the gorrillas were close by or perhaps she only used it as a safe haven in cases of emergency) that may have caused some students longer deliberations over how to tell a particular story through their displays. In a socially constructivist sense, we hoped that the interactive learning processes would serve to mediate each other's thinking and understanding about how to portray aspects of natural history science in differing ways. Through encouraging collaborative working together we anticipated that the students would solve the practical problems as they arose in the diorama construction and in so doing they would dialogically exchange understandings to clarify and make sense of the intention of the group display. In the tradition of social constructivism we assumed that the students would ....'solve practical tasks with the help of their speech, as well as with their eyes and hands' (Vygotsky 1978:26).

Engagement in the collaborative production of the dioramas with everyday materials offered a physical affordance (Norman 1999). This promoted much discussion and reflective negotiation about the possible ways that the displays could be constructed. The in-depth thinking and creativity that emerged from these purposeful dialogues was specifically recollected by the students.

\section{Students' views of learning from reviewing others' dioramas?}

Learning about natural history scientists, their life and work

It is a very similar proportion, around $80 \%$ (see Table 1), of the students who indicate they learnt about the scientists their life and work, through the interactive processes inherent in reviewing each others' dioramas. Interestingly this is not significantly different from the perceived processing of information required to make DIY (Chu 2014) dioramas! It was anticipated that perhaps the making of a diorama might involve generally more 'talking', 'thinking' and 'collective decision-making' and jointconstruction (physically as well as psychologically) about the ways to transform the information concerning natural history scientists into a realistic depiction of some kind.

Contrasting the perceived affordances offered through constructing and reviewing dioramas.

\begin{tabular}{|c|c|c|}
\hline & $\begin{array}{c}\text { Through the constructing } \\
\text { process (\%) }\end{array}$ & $\begin{array}{c}\text { Through the reviewing } \\
\text { process (\%) }\end{array}$ \\
\hline $\begin{array}{c}\text { Perceived emergent } \\
\text { understandings }\end{array}$ & 79 & 80 \\
\hline
\end{tabular}




\begin{tabular}{|c|c|c|}
\hline \multicolumn{1}{|c|}{$\begin{array}{c}\text { Learning processes } \\
\text { Involving : }\end{array}$} & 76 & 31 \\
\hline $\begin{array}{l}\text { Collaboration (discussion, } \\
\text { negotiations and decision- } \\
\text { making centred around } \\
\text { completing task, collective } \\
\text { actions contributing to } \\
\text { completing task) }\end{array}$ & 47 & 25 \\
\hline $\begin{array}{c}\text { Physical co-construction } \\
\text { skills }\end{array}$ & 27 & 4 \\
\hline
\end{tabular}

Table 2 : Students views about the learning processes inherent in making and reviewing dioramas $(n=71)$.

The students' comments about their own emergent understandings (as indicated in Table 2) when comparing constructing and reviewing dioramas appeared to be interestingly quite similar. However, the stark difference they remarked upon, was the extent to which they felt they were learning when making the dioramas rather than viewing them. They noted that there were a variety of collaborative processes engaged in (including more discussion, more task focus and more physical construction) when involved in designing and building the displays. Negotiation and decision-making were important too, as they had quite a short time within which to produce a shared outcome. The collaborative outcome of their shared endeavours was a physical 3D display depicting the life and work of a natural history scientist. Achiam et al (2014: 4) suggests that this kind of pragmatic imperative can offer physical-geometric affordance. The sequential experience of making and then reviewing others' dioramas could arguably offer the students cognitive affordances because they were in a related situation (of constructing a display) immediately prior to reflecting on, and inspecting another's display (with a similar purpose).

\section{Beginning Teachers' views about why they would use dioramas}

Most students indicated (as summarised in Table 3) they thought there were a range of benefits for learners. Suggesting why dioramas were appropriate to use for learning, just about half of the students $(49 \%)$ recognised a wide variety of learning processes involved in the construction and review processes of making the shoe-box models. They commented on the way that collaborative learning processes $(44 \%)$ together were fun (6\%) and involved discussions, exchanges of ideas, negotiations about what to include and how to make the displays. They realised that researching $(13 \%)$ for relevant information and considering ways to use resource materials creatively $(7 \%)$ to represent relevant ideas $(14 \%)$ that illustrated $(9 \%)$ and summarised $(3 \%)$ understandings all involved critical and in-depth thinking (11\%). $7 \%$ thought that using dioramas for learning would mean they were a memorable activity that $15 \%$ said could promote motor and design skills.

\section{Beginning Teachers' views about when they would use dioramas}

\begin{tabular}{|c|c|}
\hline & Percentage of student responses \\
\hline Introduction (elicitation) & 21 \\
\hline Conclusion (summative assessment) & 31 \\
\hline Make boring/dry subject matter fun & 14 \\
\hline
\end{tabular}




\begin{tabular}{|c|c|}
\hline Researching information & 24 \\
\hline (Re)Presenting information & 7 \\
\hline Cross-curricular/any subject matter & 23 \\
\hline
\end{tabular}

Table 3 : The students views about when they might use classroom dioramas as teachers $(n=71)$.

The physical ways that making dioramas offered design and material affordance for learning about more abstract ideas was recognised by the beginning teachers when they suggested that constructing and reviewing others' models could be appropriate for any aspect of learning science. They also recognised how building representative displays at the beginning or end of a topic or theme offered teachers insights into the learners' understandings. The beginning teachers also recognised how coconstructing dioramas, offered differentiation by process and outcome and therefore could be conducted in an inclusive manner for all children to be involved. Achiam et al (2014) would suggest that the use of everyday materials offered design affordance; the collaborative nature of working together offered hidden (cognitive and affective) affordances and the shared objective to produce an outcome for peers to appraise offered a perceived affordance.

\section{Discussion}

There is little research literature discussing the ways that home-made or DIY dioramas can be used to promote learning about natural history. Those studies that have been published focus mostly on examining what visitors learn from looking at professionally constructed displays in museums (Davidsson and Jakobsson 2012; Ash 2004). Many studies, therefore, have generally focused on the ways that, often permanent, large glass-cased museum displays can promote learning about habitats, ecosystems and the organisms (plants and animals) that usually live there. This chapter offers a fresh and less traditional (post modern) learning perspective.

Utilising the approach of encasing a (smaller) visually appealing shoe-box model of the work and life of a Natural History scientist there are similarities with learning from museum exhibits. This kind of home-made exhibit can open up different kinds of discussion and apprehendability, as Allen (2004) suggests this could place the children in a more comfortable framework from which to be curious. The opportunity to co-construct a material depiction of a scientist's work (and discovery) contributes to social constructivist ways of learning because the experience involves the application of both physical and mental collective processes to create a natural history diorama. In this study the processes could be scaffolded through the steps outlined below.

Dioramas traditionally built for museums are very expensive to construct (Reiss and Tunnicliffe 2011) and obviously require much expertise and time to assemble. This chapter reports on an inexpensive, interactive and rapid re-producible way that teachers and children could engage in similar learning (through stories and narratives) like those offered at museums. Affordance is offered in a wider variety of ways than Achiam et al 2014 discuss through the materials utilised for physical construction as well as the real affordance or even hidden affordances (that is the mis-match between the diorama-builders' intentions and the viewers' consequent story-making).

Additional learning processes beyond those identified by Tunnicliffe and Scheesoi (2015) can be engaged in when learners co-construct their own dioramas for others to examine and review. Set-up as collaborative endeavours, sharing responsibility for co-constructing dioramas can promote development of research skills, in-depth discussion, constructive creativity, deductive and critical thinking, all of which are 
contributory means by which teachers can support social constructive learning processes.

\section{Recommendations}

The study reported on in this chapter suggests that a post-modern turn (HooperGreenhill 2007) could be adopted to teach using dioramas. Rather than the traditional museum approach to preserving and presenting precious or rare artifacts that can only be viewed and abstractly thought about, the approach offered here suggests a more dynamic modernisation of ways in which objects or events could be re-considered. Although this 'modern' process does not involve visiting the treasured, well preserved and robust dioramas of Victorian England, the learning processes engaged in when 'visiting' and 'viewing' artifacts of cultural and scientific interest can be adopted and adapted for the everyday classroom. The learning can be extended to support meaning making through interpretations of DIY exhibits and even promote comparing and contrasting re-constructed narratives of various (similar) events or depicted realities. The process of co-constructing a shoe-box diorama to contribute to a classroom exhibition and then reviewing them, as through visiting-in-role as if at a museum offers affordance and development of distributed cognition (Achiam et al 2014). The stages that are key, though, to scaffold and mediate the learners through this enjoyable and effective learning process are :

Step 1 : Generate a focus for making dioramas that will contribute to a collection of some kind. In the activities described above the focus was the life and work of Natural History scientists. However, as the students suggested dioramas could feature any subject or event (themes proposed included the earth in space, the inside of the human body, electricity and even inventions of any kind).

Step 2 : Identify a particular event, person or object that a group should create a diorama to depict. If the groups do not know what each other are doing, this can augment the engagement in the reviewing stage (by intensifying the intrigue and focussed thinking) when it comes to generating a narrative to explain each shoe-box display.

Step 3 : Agree the success criteria for an effective diorama (as listed above). This provides clear objectives for each group to aim for.

Step 4 : Encourage collaboration to negotiate understandings, plan, design, collect materials required and co-construction a DIY diorama that is agreed to depict appropriately a particular concept or related facts and information. Working collaboratively in this way can offer affordance and develop distributed cognition through the active contributions from each member of the group. A specific length of time provides a clear target for the group to work effectively together to complete their part of the display.

Step 5 : Create a museum-like display by organising the shoe-box dioramas in a thematic way and ensuring the (initially) covered 'fact' card is completed to accompany each box.

Step 6 : Visit each others' dioramas to collaboratively (re)co-construct the particular 'stories' (with the success criteria in mind) behind each visual representation (through each shoe-box display).

Epistemologically, it seems, understanding about natural history scientists and their work can be promoted through the scaffolding of pragmatic experiences of building and examining dioramas. There are, of course, limitations to the quality (and undoubtedly detail) of the home-made dioramas. However, the processes of peerpeer mediation through working collaboratively can enhance understanding about the ways that scientific concepts have emerged from scientists particular ways of working. Supporting reflective discussions, by using questions appropriately (Ash 2004), when viewing DIY dioramas (about scientists work) to consider 'What can you see?'; 'What could it mean?'; 'How might you interpret it/those?'; Who could it be?' 
can promote reflective and collaborative considerations. Posing these kinds of questions can encourage dilemma and dialogic exchanges focused on imagining and co-constructing stories from visual depictions (of others' interpretative exhibits). This kind of scaffolded process could be perhaps, summarised as "notice-wonderinterpret-suggest" and could provide a step-by-step scaffold for younger and older learners alike.

\section{Future work}

This study reviews students' views of the building and reviewing of dioramas and considers what they think, as beginning teachers about how dioramas can be used for learning. However, to explore further, in a socio-cultural manner, the nature of different narratives that might emerge, it would be insightful to capture conversations during the different phases of diorama-making and diorama-viewing. Exploring the ways that learners use stories (Arbor 2011) and language to construct scientific knowledge could inform pedagogy about how to best use dioramas in everyday classrooms. This kind of evidence, complemented by post-activity interviews and discussions (Tunnicliffe 2007) would further illustrate the kinds of affordances that home-made dioramas offer for learning about natural history.

\section{References}

Achiam, M., May, M. and Marandino, M. (2014) Affordances and distributed cognition in museum exhibitions. Museum Management and curatorship. 29 (5) 461 - 481

Allen, S. (2004) Designs for learning : Studying science museums exhibits that do more than entertain. Science Education Supplement 88 S17 - S33

Arbor, A. (2011) Small Stories for Learning : A sociocultural analysis of children's participation in informal science education. Unpublished doctoral Thesis. Rensselaer Polytechnic Institute, New York.

Ash, D. (2004) How families use questions at dioramas : Ideas for exhibit design. Curator: The Museum Journal 47 (1) 84 - 100

Chu, E. (2014) DIY Dioramas. Popular Photography 78 (9) 42 - 43

Cole, M. (1996) Cultural psychology. A once and future discipline. Harvard : Harvard University Press

Department for Education (2013) National Curriculum: Primary National Curriculum. London: Department for Education.

Edwards, S. (2015) A hall of mirrors ; An artist's reflection on the Re-presentation of Nature in a Natural History Museum. International Journal of the Inclusive Museum 8 (1) 1 - 10

Falk, J.H. and Dierking, L.D (1992) The museum Experience. Washington, D.C. : Walesback

Falk, J.H. and Dierking, L.D (2000) Learning from Museums. Lanham, MD : AltaMira Press

Falk, J.H., Scott, C. and Dierking, L.D (2004) Interactives and Visitor Learning. Curator 47 (2) 171 - 198 
Hein, G. E. (1998) Learning in the Museum. Abingdon, Oxon : Routledge

Hooper-Greenhill, E. (2007) Museums and Education. Purposes, Pedagogy performance. Abingdon, Oxon : Routledge

Norman, D. A. (1999) 'Affordance, Conventions and Design'. Interactions 6 (3) 38 43

Piqueras, J., Wickman, P-O. and Hamza, K. M. (2012) Student teachers' moment-tomoment reasoning and the development of discursive themes - an analysis of practical epistemologies in a natural history museum exhibit. In E. Davidson and A. Jakobsson (Eds) Understanding Interactions at Science Centers and Museums. Approaching Sociocultural Perspectives. Pp 79 - 96

Reiss, M. and Tunnicliffe, S.D. (2011) Dioramas as depictions of Reality and Opportunities for Learning in Biology. Curator The Museum Journal. 54 (4) 447 459

Rennie, L. J. (2014) Learning Science Outside of School. In N. Lederman and S. Abell (Eds) Handbook of Research on Science Education. New York : Routledge pp. $120-144$

Rounds, J. (2004) Strategies for the Curiosity-Driven Museum Visitor. Curator 47 (4) $389-412$

Tunnicliffe, S. D. (2007) The role of natural history dioramas in science education. The informal learning review. 8711 - 19

Tunnicliffe, S.D. and Scheersoi, A. ( 2010) Natural History Dioramas. Dusty relics or tools for Biology Learning in (Ed) A. Filippoupoliti Science Exhibitions:

Communcation and Evaluation Museum ETC Edinburgh 186 - 217

Tunnicliffe, S. D. and Scheersoi, A. (2015) Natural History Dioramas. Dordrecht : Springer 
List of Figures :

Figure 1 : The students begin by painting their shoe boxes in an appropriate colour.

Figure 2 : This 'David Attenborough' diorama has blue acetate representing the sky.

Figure 3 : Some groups went outside the classroom to collect leaves, sticks and pebbles to add to their dioramas.

Figure 4 : Beginning teachers had to research their scientist carefully before representing them in the diorama.

Figure 5a: A final Charles Darwin diorama focused on the origin of species.

Figure $5 b$ : A final Mary Anning diorama.

Figure 5c: A final Jane Goodall diorama.

Figure 5d: A final Rachel Carson diorama.

List of tables :

Table 1 : Beginning teachers' views of perceived affordance of making and reviewing co-constructed dioramas.

Table 2 : Students views about the learning processes inherent in making and reviewing dioramas $(n=71)$.

Table 3 : The students views about when they might use classroom dioramas as teachers. 